Asian Journal of Information Technology 10 (1): 14-19, 2011

ISSN: $1682-3915$

(C) Medwell Journals, 2011

\title{
Level of Information Technology Utilization in Malaysian Secondary Schools
}

\author{
${ }^{1}$ Siti Mariam Che Hassan, ${ }^{2}$ Abdullah Mohd Zin and ${ }^{3}$ Saadiyah Darus \\ ${ }^{1}$ Faculty of Information Technology, Open University Malaysia, Kuala Lumpur, Malaysia \\ ${ }^{2}$ Faculty of Information Science and Technology, University of Kebangsaan Malaysia, Bangi, Malaysia \\ ${ }^{3}$ School of Language Studies and Linguistics, Faculty of Social Sciences and Humanities, \\ University of Kebangsaan Malaysia, Bangi, Malaysia
}

\begin{abstract}
This study was carried out to determine the level of IT utilization in secondary schools in Malaysia. About 125 respondents (100 teachers and 25 administrators) from secondary schools have participated in this study. Two sets of questionnaires were distributed and statistical methods were used to analyze data. The result of the study shows that there is significant relationship between training with the level of IT utilization in schools, there is significant relationship between IT background with the level of IT utilization in schools, there is no significant relationship between related working environment provided by the schools with the level of IT utilization in schools and there is no significant relationship between IT skill with the level of IT utilization in schools.
\end{abstract}

Key words: IT in education, IT utilization, vision 2020 , secondary schools, respondents, Malaysia

\section{INTRODUCTION}

In order to transform Malaysia into a developed country by the year 2020 (known as Vision 2020), the usage of information technology must be improved. The government has allocated a large amount of resources for the development of information technology in Malaysia. The initiative for promoting the use of information technology was started in 1990. An area between Kuala Lumpur City Center (KLCC), Putrajaya and Kuala Lumpur International Airport (KLIA) was declared as Multimedia Super Corridor (MSC).

MSC owns five Flagship Applications such as electronic government, multipurpose card, smart school, telehealth and technopreneur development. The effective integration of new and emerging technologies requires simultaneous innovation in pedagogy, curriculum, assessment and school organization (Dede, 1998). Technology usage in the management of lessons can enhance academic standard. Effective usage of technology in classrooms such as computer applications, LCD Screen, Projector and CD Courseware has shown good performance and is welcomed by various parties. In addition, the facility was improved when EduWebTV was introduced. Teachers and students could surf the Internet for teaching and learning. Usage of technology in the classroom not only creates pleasure while studying; it also enhances students performance and increases their literacy skills. Since 1996, the ministry of education has broadened usage of technology in educational field. Facilities such as computer-lab, access centre, education CD, web TV, PPSMI (learning of Science and Mathematics in English) program and school net project (The Star Online, 2010) were provided. About 1584 schools were supplied with access centre. About 5266 schools were equipped with 5266 computer labs, 132220 computers and 5266 servers. School net internet's facility was provided with 132649 laptops, 78333 projectors, 67439 screen, 63254 trolleys, 2286 televisions and 9662 printers.

Usage of student information system in school management helped teachers and administrators to check students' academic affairs such as students' information and discipline. To analyze students' academic achievement, the ministry of education provides examination system analysis that can facilitate teachers to identify the students' strength and weakness on certain subjects.

The management of students' discipline is more systematic with the use of e-discipline which is also provided by the Ministry of education. Effectiveness of usage of technology is proven with 33 schools being selected as smart school from a total of 88 schools.

Problem formulation and solution: Education in Malaysia has undergone various changes not only in terms of edagogical approaches but also in education

Corresponding Author: Siti Mariam Che Hassan, Faculty of Information Technology, Open University Malaysia, Kuala Lumpur, Malaysia 
pmanagement. Management in education has emerged as an important factor in determining the productivity of educational organization. Schools generate different products compared with other organizations. This is all the more reason why it is necessary for the administration and school management to stabilize management knowledge. Information technology is one of the factors that is found to be relatively significant since it affects how one operates, the system used and the workplace. Nevertheless, the phenomenon which occurs in Malaysia is the level of IT utilization in education management needs to be improved (Afshari et al., 2010). Previous studies found that IT utilization in schools education management is still low (Afshari et al., 2010; Abdul Razak et al., 2010). Since, then the Ministry of Education has done a lot of improvement by increasing the number of training and in-service courses as well as upgrading the IT facilities available in schools. Thus, a new study needs to be carried out to determine the current level of IT utilization. This study can then be used as an indicator to determine whether the training and other measures taken by the Ministry of education are effective or not.

Objectives: The general objective this study was to identify the level of IT utilization in secondary schools and how far it can produce IT utilization in schools. The specific objective of this study was to ensure whether training, IT skill, background, demographic factors (such as academic background, experience in school management field and so on) have significant correlation in giving and producing the level of IT utilization in schools. Specifically, this study aims to:

- Identify how far training can influence the level of IT utilization in schools

- Determine related academic background or IT skills that have an effect on the level of IT utilization in schools

- Identify how far does the working environment provided by schools has an effect on the level of IT utilization in schools

IT utilization in organization: The use of information technology is a central element in increasing the government's operational productivity and improving quality service to its clients. The main purpose of using information technology is to improve administrative efficiency, increase effectiveness in organizational aspect of management, improve organization services, making human resource management more systematic, increase awareness of the importance of information technology and enhance the capability of organizations to distribute information about management. There are two important variables in the management of an organization, namely environmental and technology. Technology that is created in an organization influences and determines organizational management structure. Through open system theory introduced by Katz and Kahn (1966), information processing is seen as a factor that determines organizational system stability. An organization can develop and becomes dynamic if information system exists.

IT utilization in schools: The use of information technology not only gives a huge impact to teaching and learning process, it also can bring impact to the management division and school administration. Efforts made towards creating efficient and effective education management should involve teachers, executives as well as decision makers. They must equip themselves and keep abreast with the latest development and knowledge on information technology. In order to ensure educational institutions maintain its function and interest as a knowledge center, excellence in management and schools' administration is of high priority.

This challenge will be felt more when the country is being affected by globalization, crowded with various challenges, including the use of modern technology in daily life. Therefore, managers at grassroots level have to understand profoundly aspects about management of administration as well as leadership.

IT tools required by teachers: IT tools are the tools that are used by teachers to complete their tasks in schools. The IT tools that are widely used are microsoft word, microsoft excel, microsoft powerpoint and microsoft access. Teachers also use internet to search information in preparing their teaching materials.

IT competency measure: Use of computers in the daily communication, knowledge of computer systems, ability to work with word processor, data management, spreadsheet and data analysis programs have become essential requirements for many positions in organizations. The degree of knowledge and proficiency required varies from one position to another based on the tasks and duties involved. Three levels of proficiency have been defined: basic, intermediate and advanced. These levels reflect the standard steps in the acquisition and development of computer skills.

Factors that influence it utilization for teachers: This study identifies four factors that influence the IT 
utilization for teachers, namely training, academic background, environment and motivation. Training or in-service course are carried out with the aim of training people in the use of techniques that can help them become better producers of ideas be more creative and better problem solvers. A number of researchers have pointed out the importance of training. McDonald (1993) emphasizes that training is one process where individual will strive to enhance comprehension and knowledge or improve their skills and ability to carry tasks better compared to their current status or prepare them to fulfill a higher position in the future. Information technology agenda must give focus to the human development aspect because success or failure of IT depends on acceptance and appreciation of all its citizens. At international level, Malaysia benefits from the training conducted by participating international agencies such as UNESCO, SEAMEO, ADB, ASEAN and Commonwealth.

In education management, INNOTECH or regional center for educational innovation and technology located in Manila trains hundreds of education managers. According to Burton (1992), academic background is another factor that influences IT usage in normal daily life. Academic achievement also influences the effectiveness of schools or the success of an organization. Academic achievement directly gives value to individuals. According to Yus of (2000), the 21 st century management show organizations employ highly knowledgeable staff. In a society, educational qualifications determine ones social status. Employees that have high level of education are more respected. They have the capability to give positive response when they communicate. Therefore, the 21 st century manager should always update their knowledge and expertise so that they can communicate better with staff having higher educational qualification. According to Holt (1993), the environment can be defined as matters that surround organization.

However, the organization boundary is not very clear. Therefore, although organization management is related to the environment, the degree of relationship is different from one organization to the other. Motivation can be defined as something that can direct behavior in a more energetic way. People have different attitude, intellectual ability, patience, skills, interest, aspiration and effort. Education, training and experiences can motivate people.

According to Holt (1993), the managers or the administrators need to have a specific objective for their organization. It is important for the organization and staff to get a clear idea about the target they have to achieve and the process to achieve the target. Yusof (2000) views that motivation results from interaction of an individual with the environment. In other words, motivation is a power that can raise and influence individuals to behave. Holt (1993) stresses that managers or administrators should know their staff well. They should know the background of their staff, attitudes, interest, need and desire especially in carrying out their research.

\section{MATERIALS AND METHODS}

About 17 schools were selected for this study: 16 schools under the ministry of education and 1 school under Pahang state government.

Research design: The research adopted a quantitative approach where questionnaires were used to collect data. Systematic random sampling was used.

Population and sample: The research samples were administrators and teachers from 17 schools. The administrators were the principal, senior administration assistant, senior assistant for student affairs and senior assistant for Co-curriculum.

Research instrument: About 2 sets questionnaires were used. The first set was for the school administrators and the second set was for the teachers. The questionnaire for school administrators consists of two sections:

Section A contains questions about respondents' demography while section $\mathrm{B}$ consists of 23 questions for administrators' perception on IT usage among teachers in teaching and job management. The questionnaire for teachers consists of three sections. Section A contains questions about respondents' demography. Section B consists of 15 questions which encompasses independent variables namely: training, academic background, environment, IT competency level, management related to IT and motivation from IT utilization. Questions in section $\mathrm{C}$ are about teachers' IT skills.

Data collection methods: About 25 sets of questionnaires were given to the administrators while 100 sets of questionnaires were given to the teachers. Before the survey questionnaires were circulated to administrators and teachers, they were briefed on the objective of the study and informed that all information given for this study will be treated as confidential. The questionnaires were collected after 1 week.

Analysis of data: Data was analysed using SPSS (Version 14). To test the hypothesis and achieve the aims of the study, cross-tab, frequency and simple pearson correlation (to foresee the degree of frequency and 
relationship with independent variables and dependent variables) were used. These techniques were chosen because it can explain the degree of association and the strength between the tested variables.

\section{RESULTS AND DISCUSSION}

About 125 sets of questionnaire were distributed to school administrators and teachers using systematic random sampling.

All respondents returned their questionnaires. Researchers analyzed the data in the form of descriptive statistics and inference. Descriptive discussion was made to explain respondents' background, level of IT utilization between school administrators and teachers especially in implementing the task related to IT. Analysis in inference and hypotheses testing are made by using cross-tabs and pearson correlation. Significant level for this study was fixed at $\mathrm{p}<0.05$.

Descriptive respondent information: About 94\% of respondents have a Bachelor's degree while $6 \%$ have Master's degree. About 52\% of teachers have gone through formal computer training either through in-service courses organized by the ministry of education or training from private parties while $48 \%$ of them have never undergone formal computer training.

Majority of the administrators $(52 \%)$ are not trained to use computers. In terms of research experience, $35 \%$ of the teachers have worked for $>10$ years, $38 \%$ worked between $5-10$ years and $27 \%$ worked $<5$ years. Most of the administrators have researched for $>10$ years.

Teachers' perception on IT: Teachers' perception on IT is shown in Table 1.

Teachers competency level in IT: The teachers competency level in IT was measured based on their skills in using software application and internet. The result of the study shows that most of the teachers are able to use word processor such as microsoft word effectively for preparing documents. Most of them can use functions such as creating new document, insert text and save files $(97 \%)$, print document (98\%), cut and paste (96\%) and find and replace $(88 \%)$. However, a significant number do not have the skill to insert table $(40 \%)$, insert multimedia picture $(57 \%)$ and use mail merge (74\%). Similarly, most of the teachers are confident in using spreadsheet. Most of them are able to open file, use page setup and save file (91\%), format cells, row and column $(92 \%)$ and print spreadsheet $(89 \%)$. However, most of the teachers are not familiar with advanced functions such as names, VLOOKUP and IF where only $35 \%$ of the teachers know how to use them. Teachers are also familiar with the use of presentation software such as microsoft powerpoint. Most of them know how to create slides (87\%), edit text, use ClipArt and WordArt $(87 \%)$, insert table and charts $(86 \%)$, use slide transitions and custom animation $(83 \%)$ and print slides $(83 \%)$. Only a small number of teachers are familiar in using database.

For example, only $41 \%$ indicated that they know how to create new record or new table, $37 \%$ know how to sort and edit record and $27 \%$ know how to create query. For programming the database, only $18 \%$ know how to use macros and $18 \%$ are able to use VB to create modules. Teachers have mixed ability in using the internet. Most of them know how to use the internet browser such as internet explorer or Mozilla (88\%) and use webmail (86\%). However, only a smaller number of teachers are familiar with other functions on the internet such as playing online games $(55 \%)$, joining forum or blog $(64 \%)$ and making online transaction (54\%).

IT utilization: Table 2 shows IT utilization among teachers and administrators. These 23 tasks indicate the level of IT utilization among teachers and administrators. 
Asian J. Inform. Technol., 10 (1): 14-19, 2011

Table 2: IT utilization among teachers and administrators

\begin{tabular}{lcc} 
Tasks & Teacher (\%) & Admin (\%) \\
Type letters using MS Word & 89 & 88 \\
Prepare teaching record/teaching aid material using MS Word & 58 & 80 \\
Provide certificate using mail merge method & 33 & 76 \\
Preparing a report/minutes of meeting using MS Word & 90 & 62 \\
Make programme pamphlet & 94 & 76 \\
Prepare test questions using MS Word & 50 & 76 \\
Build arrival of student system/student scores using MS Excel & 50 & 76 \\
Record activity using MS Excel & 53 & 72 \\
Make graphs of student scores using MS Excel & 54 & 72 \\
Prepare slide presentation for teaching & 39 & 72 \\
Using CD courseware provided by Ministry of Education & 27 & 80 \\
Build Student Information System (SMM) using MS Access & 43 & 64 \\
Use information system provided by Ministry of Education & 19 & 33 \\
Build website/blog & 27 & 60 \\
Communicate with teacher/student using e-mail & 68 & 44 \\
Use forum as discussion tool for teaching and learning & 56 & 44 \\
Find instructional material on internet & 40 \\
Download video/music from internet & 46 \\
Use the computer for teaching & 31 \\
Use LCD/slide projector during teaching and leaming & 37 \\
Use a scanner for examination & 45 & 52 \\
Use computerized system to record teacher/student arrival & 44 \\
Use computer and LCD when conducting meetings & & 80 \\
\hline
\end{tabular}

Administrators were asked whether they expected teachers to use IT for doing these tasks. In teachers questionnaire, they were asked whether they used IT for each of the tasks. From Table 2, it shows that there are only four tasks that teachers utilization of IT exceeds administrator's expectation.

Hypothesis testing: Four hypotheses have been identified and tested using Correlation Pearson analysis.

$\mathbf{H O}_{1}$ : There is significant relationship between training with the level of IT utilization in schools. Pearson correlation analysis was used to test the relationship between training/course with IT levels of utilization in schools. The analysis shows that there is a positive correlation with medium relationship at 0.05 significant level between training/course with usage of IT levels in school with $r=0.456$ value and $p=0.00$. Thus, there is a significant relationship between training/course with utilization of IT levels in schools.

$\mathbf{H O}_{2}$ : There is significant relationship between IT academic backgrounds with the level of IT utilization in schools. Pearson correlation analysis was used to test the relationship between IT background and IT levels of utilization in school. The analysis shows that there is a positive correlation with a higher relationship at 0.05 significant level between IT academic background with IT levels of utilization in school with $\mathrm{r}=0.504$ value and $\mathrm{p}=0.00$. Thus there exists a significant relationship between IT academic background with IT levels of utilization in schools.
$\mathbf{H O}_{3}$ : There is significant relationship between related working environment provided by the school with the level of IT utilization in schools. Pearson correlation analysis was used to test the relationship between the factor conveniences of IT environment provided by the school with IT levels of utilization in school. The analysis shows that there is a positive correlation with very strong relationship at 0.05 significant level between convenience of working environment with IT levels of utilization in school with $r=0.75$ value and $p=0.228$. Thus, there is no significant relationship between IT facilities with IT levels of utilization in school.

$\mathbf{H O}_{\mathbf{4}}$ : There is significant relationship between IT skill with the level of IT utilization in schools. Pearson correlation analysis was used to test the relationship between the IT skill with IT levels of utilization in schools. The analysis shows that there is a positive correlation with low relationship at 0.05 significant level 0.05 between IT skill with IT levels of utilization in schools with $r=0.248$ value and $p=0.228$. Thus, there is no significant relationship between IT skills with IT levels of utilization in schools.

\section{CONCLUSION}

The aim of this study was to study the levels IT of utilization in secondary schools. About 125 participants were selected by using systematic random sampling; 25 school administrators and 100 teachers. All respondents submitted their questionnaire. The data was analyzed using SPSS software (version 14.0) for percentages and frequencies. Pearson coefficient value was used to explain 
the relationship between independent variables and dependent variables. Significant level for this study was fixed at $\mathrm{p}<0.05$.

To identify how far training can influence the level of IT utilization in schools. The result shows that the factor training/course was very positive in influencing IT levels of consumption in school. As much as $95 \%$ of the respondents agreed that the factor training/course really influenced IT levels of consumption in school. The result is consistent with. This study also clearly supports (Yusof, 2000) view which states that training/course is very important to increase someone's knowledge and skill. In his view, training is one of the key components in an effort to increase staff performance. As training/course is important in enhancing a person's skills and knowledge, this aspect should be given attention by the Ministry of Education, State Education Department and District Education Office.

Determine related academic background or IT skills that have an effect on the level of IT utilization in schools. The result of the study reveals that academic background and IT skills are positive in influencing IT levels of utilization in schools. As much as $85 \%$ of the respondents agreed that academic background/relevant skills in IT influence IT levels of utilization in schools. Identify how far does the working environment provided by schools has an effect on the level of IT utilization in schools. The result shows that the facilities provided by the schools (IT related aspect) is not quite encouraging because only $54 \%$ of the respondents agreed. This shows that the working environment needs to be further improved.

\section{REFERENCES}

Abdul Razak, N., M.A. Lubis, M.A. Embi and R. Mustapha, 2010. IT literacy of language teachers in Malaysian Technical schools. Int. J. Educ. Inform. Technol., 4: 149-156.

Afshari, M., K. Abu Bakar, S.L. Wong and M. Afshari, 2010. Principals level of computer use and some contributing factors. Int. J. Educ. Inform. Technol., 4: $121-128$.

Burton, P.F., 1992. Information Technology and Society. Library Association Publishing, London.

Dede, C., 1998. The Scaling-up Process for Technology Based Educational Innovations. In: Learning with Technology, Dede, C. (Ed.). Association for Supervision and Curriculum Development, Alexandria, VA, pp: 199-215.

Holt, D.H., 1993. Management: Principles and Practice. 3th Edn., Prentice Hall, New Jersey.

Katz, D. and R.L. Kahn, 1966. The Social Psychology of Organizations. Wiley, New York.

McDonald, S., 1993. Information technology: Building structures in initial teacher training to develop effective practitioners. J. Comput. Assisted Learning, 9: 141-148.

The Star Online, 2010. SchoolNet bridges digital divide. http://thestar.com.my/news/story.asp?file $=/ 2010 / 10 / 3 /$ nation $/ 7137232 \& \mathrm{sec}=$ nation.

Yusof, A.A., 2000. Modul lengkap: Gelagat organisasi. Universiti Utara Malaysia, Sekolah Pengurusan. 